Sains Malaysiana 47(5)(2018): 977-989

http://dx.doi.org/10.17576/jsm-2018-4705-13

\title{
Inclusion of Curcumin in $\beta$-cyclodextrins as Potential Drug Delivery System: Preparation, Characterization and Its Preliminary Cytotoxicity Approaches
}

(Penambahan Kurkumin dalam $\beta$-siklodekstrin sebagai Potensi Sistem Penyampaian Ubat: Penyediaan, Pencirian dan Pendekatan Awal Kesitotoksikan)

\author{
MUHAMMAD HASNOR JA'FAR, NiK NuR SYAZNi NiK MOHAMED KAMAL, BOON YiH HuI, MuHAMMAD FAHMI \\ KAMARUZZAMAN, NUR NADHIRAH MOHAMAD ZAIN, NOORFATIMAH YAHAYA \& MUGGUNDHA RAOOV*
}

\begin{abstract}
The development and application of organic based drug carrier in drug delivery system (DDSs) with greater efficacy and fewer side effects remains a significant challenge in modern scientific and medical research. The aim of current study was to evaluate the ability of $\beta$-cyclodextrin $(\beta-C D)$ as drug delivery carrier to encapsulate Curcumin (CUR), a promising chemotherapeutic that exhibits low aqueous solubility and poor bioavailability forming inclusion complex by kneading method to enhance its delivery to cancer cells. Different methods and analysis such as Fourier Transform Infrared (FTIR) spectrometer, ${ }^{1}$ H Nuclear Magnetic Resonance ( ${ }^{1} H$ NMR), X-Ray Diffraction (XRD), Scanning Electron Microscope (SEM) and Thermo-gravimetric Analysis (TGA) were employed to approve the successful formation of the inclusion complex where the aromatic ring of CUR has been encapsulated by the hydrophobic cavity of $\beta$-CD. UV absorption indicated that $\beta$-CD complex with CUR with an apparent formation constant of $1.09 \times 10^{-8} \mathrm{~mol}^{-1} \mathrm{dm}^{-3}$. Based on the data obtained by methylthiazole tetrazolium (MTT), $\beta$-CD showed that not only did it enhanced Curcumin delivery, but it also improved and promoted the anti-proliferative effect of CUR during the complexation rather than CUR alone on the MCF-7 human breast cancer cells at $24 \mathrm{~h}$ incubation period with $I C_{50}$ lower than that of Curcumin alone. The toxicities of the $\beta$-CD-CUR towards MCF-7 cells were also compared to the free tamoxifen, Curcumin and $\beta$-CD. This study provides a preliminary toxicity evaluation based on $\beta$-CD-CUR inclusion complex as potential delivery system towards the selected cancer cells.
\end{abstract}

Keywords: $\beta$-cyclodextrin; Curcumin; cytotoxicity; inclusion complex

\section{ABSTRAK}

Perkembangan dan penggunaan pengangkut ubat organik dalam sistem pengangkutan ubat (DDSs) dengan lebih berkesan dan kesan sampingan yang sedikit masih menjadi cabaran besar dalam penyelidikan sains dan perubatan moden. Objektif kajian ini adalah untuk menilai keupayaan $\beta$-siklodekstrin ( $\beta$-CD) sebagai pengangkut ubat untuk merangkumkan Kurkumin (CUR), satu kemoterapeutik yang mempunyai kelarutan air dan ketersediaan biologi rendah agar dapat membentuk kompleks inklusi dengan cara menguli untuk meningkatkan penghantarannya ke sel kanser. Kaedah pencirian seperti inframerah transformasi Fourier (FTIR), ${ }^{1}$ H Resonans Magnet Nukleus $\left({ }^{1} H\right.$ NMR), pembelauan sinar-X (XRD), Mikroskop Elektron Pengimbas (SEM) dan Analisis -Gravimetrik Terma (TGA) telah digunakan untuk membuktikan pembentukan kompleks inklusif dengan gelang aromatik CUR telah dirangkumkan dalam rongga hidrofobik $\beta$-CD. Penyerapan ultra-lembayung (UV) menunjukkan kompleks $\beta$-CD dengan CUR mempunyai pembentukan pemalar ketara $1.09 \times 10^{-8} \mathrm{~mol}^{-1} \mathrm{dm}^{-3}$. Berdasarkan data methylthiazole tetrazolium (MTT), $\beta$-CD bukan sahaja meningkatkan pengangkutan Kurkumin malahan menambah baik dan mempromosikan kesan anti-proliferatifnya semasa kompleks pada MCF-7 sel kanser payudara manusia dalam tempoh inkubasi 24 jam dengan IC50 lebih rendah daripada Kurkumin sahaja. Toksiksiti $\beta$-CD-CUR terhadap sel MCF-7 juga dibandingkan dengan tamoxifen, Kurkumin dan $\beta$-CD asli. Kajian ini berjaya menyediakan penilaian ketoksikan awal berdasarkan rangkuman kompleks $\beta$-CD-CUR sebagai sistem pengangkutan ubat yang berpotensi ke arah sel-sel kanser yang dipilih.

Kata kunci: $\beta$-siklodekstrin; kesitotoksikan; Kurkumin; rangkuman kompleks

\section{INTRODUCTION}

Nowadays, design and development of high performance drug delivery systems (DDSs) have gained great attention by government, scientists and pharmaceutical industry. In fact, the main purpose of an ideal drug delivery systems is to improve the therapeutic efficiency and/or targeted the drugs to desire region while simultaneously reducing the side effects and increase the desired effects of drugs. The naturally derived cytotoxicity agents such as Curcumin (Bar-Sela et al. 2010) play potential roles in synergizing our current modality of cancer treatments, including chemotherapy in cancer treatment. Without a good drug delivery carrier, it will cause a poor pharmacokinetic profiles and low specificity of these drugs which may affect 
their therapeutic efficacy (Bar-Sela et al. 2010). Thus, choosing an appropriate drug delivery carrier is prior to the success of a DDS.

Cancer is the leading cause of death worldwide with an estimated 84 million casualty between 2005 and 2015 (Ucar et al. 2017). In conjunction to this, breast cancer is the most commonly diagnosed cancer in women around the world (Danhier et al. 2010). Changes in reproductive factors, environmental exposures, and lifestyle such as dietary uptake and physical activity are the major concerns contributing to breast cancer. Hence, early detection and treatment play a vital role in survival of a patient. However, due to low solubility of most cytoxicity drugs caused by their hydrophobic nature, their efficacies are described to be reduced in the patient's body (Jabbarzadeh et al. 2014), thus, higher concentration of chemotherapeutic drugs need to be prescribed during treatment. Therefore, it is imperative to find an ideal drug delivery carrier in reducing the conventional dosage of chemotherapeutic drugs without hampering their efficacy in killing those cancerous cells. Among the drug delivery carriers that can be considered for the drug delivery system (DDS), $\beta-C D$ possesses good potential due to its ability to alter physical, chemical and biological properties of guest molecules by forming an inclusion complex in both solid and solution state, respectively (Memisoglu-Bilensoy et al. 2005). The main advantages of natural cyclodextrins as a drug carrier include a well-defined chemical structure, allowing space for potential sites for chemical modification, availability of different cavity sizes from $\alpha$-, $\beta$ - and $\gamma$-cyclodextrin, low toxicity, good pharmacological activity and most importantly, its ability to enhance drug solubility in aqueous solution and affects the chemical characteristics or physicochemical properties of the encapsulated drug. Therefore, $\beta-\mathrm{CD}$ is a suitable candidate to transport the drugs to their target.

Curcumin or Curcuma longa (Figure 1), commonly known as diferuloyl methane, is a hydrophobic polyphenol derived from rhizome (turmeric) of the herb which is known to exhibit anti-cancer properties. CUR has been widely studied for its potential to protect cardiovascular disease and has been utilised in neurodegenerative disorders, especially Alzhermer's and Parkinson's disease (Fermeglia et al. 2003). Besides, CUR also possesses properties such as agent for anti-inflammatory, antioxidant, immunomodulatory, pro-apoptotic and antiangiogenic, as well as chemoprevention agent towards colon, pancreatic, cervical cancers and Barrrets mataplasia (Wilken et al. 2011). However, CUR has a limited pharmaceutical application due to its low water solubility, poor bioavailability (Yu \& Huang 2010), chemical instability and rapid metabolism (Salem et al. 2015) which may be corresponding for the pharmacokinetics restriction of this molecules (Holder et al. 1978). Therefore, to further the clinical application of CUR, the search for an efficient and nontoxic carrier for CUR has become more significant. Various methods have been applied to enhance Curcumin delivery, such as incorporating it into phospholipid vesicles (Sou et al. 2008), liposomes (Li et al. 2005)this transcription factor is a potential target for the treatment of this devastating disease. Curcumin (diferuloylmethane, and nanoparticles (Khan et al. 2016). Thus, to address the issue related to low solubility of CUR, $\beta$-CD is investigated on its suitability as a drug carrier in this study.

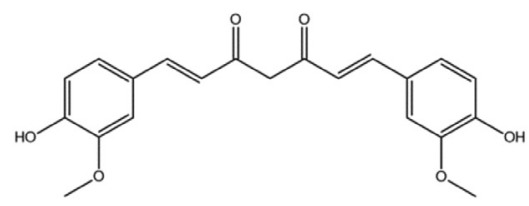

FIGURE 1 . The chemical structure of CUR

Although many studies have been carried out with $\beta$-CD (Wang et al. 2007; Zhang et al. 2015) and Curcumin (Gafner et al. 2004; Liu et al. 2013) or both (Mangolim et al. 2014); to the best of our knowledge, studies of $\beta$-CD-CUR inclusion complex focus on its anti-cancer activity in particular towards estrogen receptor (ER) positive human breast cancer cell line (MCF-7 cells) in the scientific literature are scarce and lack reported. Based on reviews, Memisoglu-Bilensoy et al. (2005) loaded $\beta$-CDC6 nanospheres into Tamoxifen citrate nanocapsules against MCF-7 cells while Yu and Huang (2010) capsulated the Curcumin into polymer micelles formed by hydrophobically modified starch and tested on human hepatocellular carcinoma cell line HepG2. Both studies demonstrated an efficient anti-proliferative effect of both cytotoxic agents in the presence of those biopolymers. Meanwhile, Jahed et al. (2014) demonstrated the molecular modelling for $\beta$-CD-CUR complex, however, assessment on the cytotoxic activity of this complex was not shown in this study. No toxicity study was performed to show the anti-proliferative of the complex. Therefore, we believe this work may enhance the fundamental value towards the supramolecular interaction between $\beta-\mathrm{CD}$ and Curcumin, particularly on their anti-proliferative effect in MCF-7 cells. Nevertheless, complexation with cyclodextrins is a popular combination which may lead to new era for their wide applications in different fields to improve the biological activities of Curcumin in living systems.

\section{MATERIALS AND METHODS}

\section{INSTRUMENTATION}

The Nuclear Magnetic Resonance ${ }^{1} \mathrm{H}$ (NMR) spectrum of the samples in dimethyl sulfoxide was recorded using Jeol JNM-GSX 270 at room temperature. The Fourier Transform Infrared (FTIR) spectra were recorded on a Perkin Elmer, System 2000 with samples prepared using Attenuated Total Reflection (ATR) technique. Scanning Electron 
Microscope Zeiss Supra 50 vP was used to obtain the surface morphology of the host, guest, and host-guest inclusion complex $(\beta \mathrm{CD}$-CUR) at $5000 \times$ magnification . $\mathrm{X}$-Ray Diffraction (XRD) analysis was analysed using $\mathrm{Cu}$ $\mathrm{K} \alpha$ irradiation with a Siemens D5000 X-ray diffractometer.

\section{SYNTHESIS OF THE INCLUSION COMPLEX OF $\beta$-CD AND CURCUMIN}

Inclusion complex between $\beta \mathrm{CD}$ with CUR was prepared using the kneading method. $0.5 \mathrm{~g}$ of $\beta \mathrm{CD}$ and $0.16 \mathrm{~g}$ of CUR were weighed and kneaded with mortar and pestle in minimum ethanol for $20 \mathrm{~min}$ to prepare a $1: 1$ ratio complex. The mixture was dried in a desiccator for $48 \mathrm{~h}$ to constant mass and weighed. The yield percentage for $\beta$ CD-CUR inclusion complex was $79.94 \%$. The powder was stored at room temperature.

\section{SPECTROSCOPIC STUDIES}

Spectroscopic studies were carried out to determine the absorption spectrum, stoichiometry, and formation constant of the $\beta$-CD-CUR inclusion complex. A UV-Visible spectrophotometer with $1 \mathrm{~cm}$ quartz cells was used for all the following spectroscopic studies. Absorption spectra were determined between 300 and $500 \mathrm{~nm}$ (Wang et al. 2007).

\section{EFFECT OF $\mathrm{pH}$}

Effect of $\mathrm{pH}$ for inclusion complex formation was determined by using three different $\mathrm{pH}$ buffers. Buffer solutions with $\mathrm{pH} 4, \mathrm{pH} 7$ and $\mathrm{pH} 10$ have been used to determine the optimum $\mathrm{pH}$. Subsequently, the optimum $\mathrm{pH}(\mathrm{pH} 7)$ has been used for the absorption spectra and the formation constant.

\section{ABSORPTION SPECTRA}

Absorption spectra were recorded for $\beta \mathrm{CD}$, Curcumin and inclusion complex with $0.0032 \mathrm{M}$ of $\beta \mathrm{CD}$ and $0.00005 \mathrm{M}$ of CUR.

\section{STOICHIOMETRY AND FORMATION CONSTANT}

The concentration of $\beta$-CD was varied in the range 0-0.005 $\mathrm{M}$ while the concentration of Curcumin was held constant at $0.00005 \mathrm{M}$. The data obtained were used to illustrate reciprocal plot for Curcumin- $\beta \mathrm{CD}$ inclusion complex using Benesi-Hildebrand equation (Kuntz et al. 1968).

\section{CELL CULTURE AND REAGENTS}

Roswell Park Memorial Institute-1640 medium (RPMI1640 medium) (Gibco BRL, UK), Fetal Bovine Serum (FBS) (Gibco BRL, UK), 10X phosphate buffer saline (Gibco BRL, UK), trypsin $0.25 \%$ EDTA $0.003 \%$ (Gibco BRL, UK) and penicillin/streptomycin solution $10 \mathrm{mg} / \mathrm{mL}$ (Gibco BRL, UK) were used in this study for cell culture and treatment. MCF-7 human breast cancer cell line was maintained in a humidified $37^{\circ} \mathrm{C}$ incubator with $5 \% \mathrm{CO}_{2}$. All procedures were conducted in a class 2 Biohazard Cabinet with a proper aseptic technique. Good cell practice guidelines were followed throughout the project.

\section{PREPARATION OF INCLUSION COMPLEX FOR TREATMENT}

$\beta$-CD-CUR inclusion complex were dissolved in $25 \mathrm{~mL}$ of DMSO and shaken. $0.5 \mathrm{~mL}$ of the solution was further diluted in $10 \mathrm{~mL}$ volumetric flask with RPMI complete growth medium and labelled as stock solution. The stock was filtered with $0.22 \mu \mathrm{m}$ sterile nylon filter before further dilution with complete growth medium to produce different concentrations $(50,100,150,200$ and $250 \mu \mathrm{M})$.

\section{PREPARATION OF CUR AND B-CD FOR TREATMENT}

$1 \mathrm{~g}$ of CUR was dissolved in $25 \mathrm{~mL}$ DMSO. $0.5 \mathrm{~mL}$ of the solution was diluted in $10 \mathrm{~mL}$ volumetric flask with RPMI complete growth medium and labelled as stock solution. The stock was filtered with $0.22 \mu \mathrm{m}$ sterile nylon filter before further dilution with complete growth medium to produce different concentrations $(50,100,150,200$ and $250 \mu \mathrm{M})$.

\section{MTT CELL PROLIFERATION ASSAY}

The MTT Cell Proliferation Assay (Merck Millipore, Germany) was used to determine the anti-proliferative effect of $\beta \mathrm{CD}$, CUR, $\beta \mathrm{CD}-\mathrm{CUR}$ 1:1 complexes on MCF-7 cell line.

\section{TREATMENT CONTROL}

Treatment controls were set up to determine the percentage of cell viability after treatment with inclusion complex, CUR alone, and $\beta$-CD alone. Table 1 shows the positive control, negative control, and background control used in the experiment.

TABLE 1 . The controls used for MTT assay

\begin{tabular}{cc}
\hline Type of control & Control used \\
\hline Positive control & $50 \mu \mathrm{M}$ Tamoxifen \\
Negative control & $\begin{array}{c}\text { Complete growth medium } \\
\text { (untreated cells) }\end{array}$ \\
Background control & $\begin{array}{c}\text { Blank wells with growth medium } \\
\text { without cells }\end{array}$ \\
\hline
\end{tabular}

\section{TREATMENT OF CELL FOR MTT ASSAY}

MCF-7 cells were harvested from the $T 75 \mathrm{~cm}^{2}$ culture flasks using trypsin-EDTA and seeded at 10,000 cells per well in a 96-well plate. The plate was incubated overnight at $37^{\circ} \mathrm{C}$ with $5 \%$ for cells attachment. The culture medium was then replaced by assay medium containing treatment with $\beta \mathrm{CD}$, CUR and $\beta$ CD-CUR 1:1 complex. Positive control, negative control, and background control were also included in the 
assay. All treatments and controls were prepared and loaded in triplicates. The plates were incubated for 24 and $48 \mathrm{~h}$.

PREPARATION OF [3(4,5-DIMETHYLTHIAZOL-2YL)-2,5DIPHENYLTETRAZOLIUM BROMIDE)] (MTT) SOLUTION

MTT solution was prepared at $5 \mathrm{mg} / \mathrm{mL}$ which was dissolved in phosphate buffer saline (PBS) and mixed well. The solution was filtered using $0.22 \mu \mathrm{m}$ sterile nylon filter and kept at $4^{\circ} \mathrm{C}$ in the dark.

\section{DETERMINING CELL VIABILITY PERCENTAGE}

At each time point, $10 \mu \mathrm{L}$ of MTT $(5 \mathrm{mg} / \mathrm{mL})$ was added to each well and the plate was incubated for $4 \mathrm{~h}$ at $37^{\circ} \mathrm{C}$ with $5 \% \mathrm{CO}_{2}$. The medium containing the MTT solution was discarded and replaced with $100 \mu \mathrm{L}$ of DMSO. The optical density of each well was read at $570 \mathrm{~nm}$ wavelength using microplate reader. The percentage of cell proliferation was calculated using (1) (Wan Omar et al. 2016):

$\begin{aligned} & \% \text { of cell } \\ & \text { proliferation }\end{aligned}=\frac{\text { Absorbance sample }- \text { Absorbance blank }}{\text { Absorbance untreated }- \text { Absorbance blank }} \times 100 \%$

\section{STATISTICAL ANALYSIS}

All data were assayed in three independent experiments. The results were displayed as the mean \pm standard deviation (S.D). Statistical analyses were determined using nonparametric Independent t-test using IBM SPSS statistics version 19 (IBM Inc., USA) since the sample size was $<30$.

\section{RESULTS AND DISCUSSION}

\section{CHARACTERIZATION}

Fourier Transform Infrared (FTIR) Analysis FTIR is a useful tool to confirm the formation of a host-guest inclusion complex. The spectrum of the inclusion complex looks almost similar to the pure $\beta \mathrm{CD}$ indicating a formation of an inclusion complex as demonstrated in Figure 2. The FTIR spectrum of CUR exhibited an absorption band at $3510 \mathrm{~cm}^{-1}$ indicating the presence of phenolic stretching vibration. Furthermore, a sharp absorption at $1602 \mathrm{~cm}^{-1}$ (stretching vibration of the CUR benzene ring), $1507 \mathrm{~cm}^{-1}$ (vibration of $\mathrm{C}=\mathrm{O}$ and $\mathrm{C}=\mathrm{C}$ of CUR), $1429 \mathrm{~cm}^{-1}$ (Coolefinic C-H bending vibration), 1275 $\mathrm{cm}^{-1}$ (aromatic C-O stretching vibrations) and 1026/857 $\mathrm{cm}^{-1}$ (C-O-C stretching vibration of CUR) confirms the presence of the functional groups in CUR.

The FTIR spectra of $\beta$-CD show characteristic peaks at 3333 and $2922 \mathrm{~cm}^{-1}$ caused by the $\mathrm{O}-\mathrm{H}$ and $\mathrm{C}-\mathrm{H}$ stretching of vibration. Besides that, peaks at 1653,1276, 1025 and $858 \mathrm{~cm}^{-1}$ indicates the presence of $\mathrm{HOH}, \mathrm{C}-\mathrm{O}, \mathrm{C}-\mathrm{O}-\mathrm{C}$ stretching glucose units and $\mathrm{C}-\mathrm{O}-\mathrm{C}$ of rings of $\beta-\mathrm{CD}$. In the case of inclusion complex between $\beta$-CD and CUR, all the sharp peaks belonging to the $\beta$-CD exist and only a few characteristics of CUR peaks are visible. The shifts to all $\beta$-CD related peaks were shifted to a higher or lower wavelength such as at 3333 to $3336 \mathrm{~cm}^{-1}, 1653$ to 1627 $\mathrm{cm}^{-1}$ and 858 to $857 \mathrm{~cm}^{-1}$. The broader $\mathrm{OH}$ stretching band of the inclusion complex in the frequency $3336 \mathrm{~cm}^{-1}$ again corresponds to the multiple $\mathrm{OH}$ functional groups of $\beta-\mathrm{CD}$ molecules (Subramaniam et al. 2010; Williams III et al. 1998). Therefore, these data confirm the presence of CUR and $\beta-\mathrm{CD}$ in the $\beta \mathrm{CD}-\mathrm{CUR}$ inclusion complex.

Table 2 shows the differences in frequencies between $\beta-\mathrm{CD}$ and their inclusion complex measured in intensity changes $\delta$ ). The increment was due to the insertion of benzene ring from CUR into the electron rich cavity of $\beta-C D$, which increases the density of electron cloud and causes frequency to increase. Whereas, decline in frequency between the inclusion complex and CUR (Table 3 ) is caused by the changes in the microenvironment that leads to the formation of hydrogen bonding and van der Waals forces in their interaction during the complexation (Jahed et al. 2014). Thus, the FTIR spectra prove the formation of the $\beta$ CD-CUR inclusion complex.

\section{X-RAY DIFFRACTION (X-RD) ANALYSIS}

$\mathrm{X}$-ray diffraction (XRD) provides further confirmation for the formation of an inclusion complex and it is commonly used to determine the formation of a new compound from

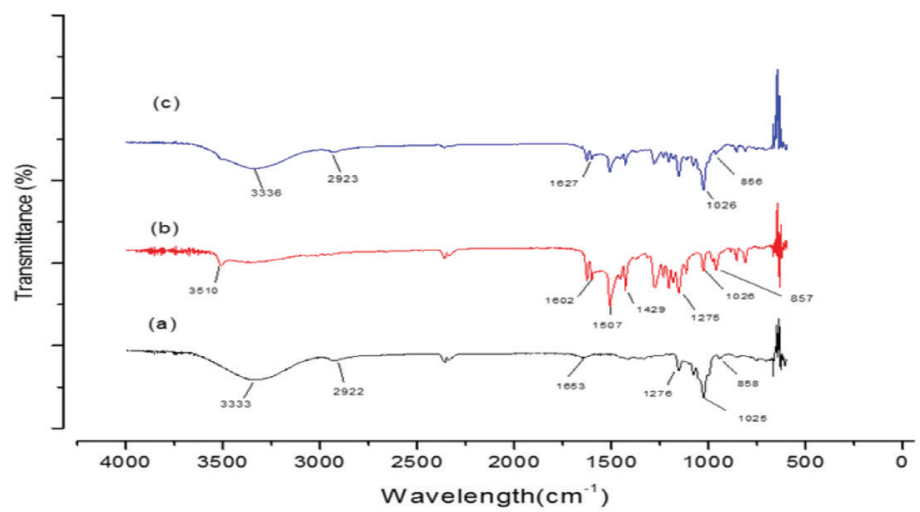

FIGURE 2. FTIR spectra of (a) $\beta$-CD, (b) CUR, and (c) $\beta$-CD-CUR inclusion complex 
TABLE 2. Comparison between the intensity of $\beta-\mathrm{CD}$ and the inclusion complex of $\beta$-CD-CUR

\begin{tabular}{lccc}
\hline Functional Group & \multicolumn{2}{c}{ Wavenumber $\left(\mathrm{cm}^{-1}\right)$} & Changes \\
\cline { 2 - 3 } & $\beta-\mathrm{CD}$ & Inclusion complex & $\delta$ \\
\hline$[\mathrm{OH}]$ symmetric and anti-symmetric & 3333 & 3336 & +3 \\
{$[\mathrm{CH}]$} & 2922 & 2923 & +1 \\
{$[\mathrm{C}-\mathrm{O}-\mathrm{C}]$} & 1025 & 1026 & +1 \\
\hline
\end{tabular}

TABLE 3. Comparison between the intensity of CUR and the inclusion complex of $\beta$-CD-CUR

\begin{tabular}{lccc}
\hline Functional Group & \multicolumn{2}{c}{ Wavenumber $\left(\mathrm{cm}^{-1}\right)$} & $\begin{array}{c}\text { Changes } \\
\delta\end{array}$ \\
\cline { 2 - 3 } & CUR & Inclusion complex & -174 \\
\hline$[\mathrm{OH}]$ & 3510 & 3336 & -176 \\
\hline
\end{tabular}

their original molecules (Zhang et al. 2015). The X-ray diffractogram of CUR and $\beta$-CD exhibited sharp, thin and intense peak which showed their characteristic crystalline peaks. This is in accordance with previous reports of $C D$ inclusion complexes (Mangolim et al. 2014; Yallapu et al. $2010)$. $\beta$-CD has a major peak at $2 \theta=9.5^{\circ}, 11.1^{\circ}$ and $12.8^{\circ}$ while CUR has a characteristic peak at $2 \theta=8.9^{\circ}, 14.8^{\circ}$ and $19.6^{\circ}$. In the formation of inclusion complex, the peaks at $2 \theta=9.5^{\circ}, 11.1^{\circ}$ and $12.8^{\circ}$ of $\beta C D$ decreased in intensity and sharpness (Figure 3). Besides that, characteristic peaks of CUR at $2 \theta=8.9^{\circ}, 14.8^{\circ}$ and $19.6^{\circ}$ also lost their intensity and broadening. The loss of intensity and increase in peak broadness indicate reduction in degree of crystallinity in the inclusion complex (Mangolim et al. 2014). This reduction showed that the complex may be converted from the crystalline into the slightly amorphous form, thereby increasing the rate of CUR dissolution (Rachmawati et al. 2013). Therefore, the formation of an inclusion compound between $\beta$-CD and CUR was confirmed.

\section{${ }^{1} \mathrm{H}$ NUCLEAR MAGNETIC RESONANCE (NMR) SPECTRA ANALYSIS}

${ }^{1} \mathrm{H}$ NMR is a useful tool to confirm the formation of an inclusion complex and to provide useful information on the inclusion mechanism of $\beta$-cyclodexrin and the guest molecule (Mohamad et al. 2011). The NMR spectrum of the inclusion complex and their parent molecules can be observed in Figure 4.

The chemical shifts between $\beta-\mathrm{CD}$ and the inclusion complex can be seen in Table 4 . The data showed that the most obvious chemical shifts occurred at H-3 and $\mathrm{H}-5$ which are located inside the cavity of the $\beta-\mathrm{CD}$. The spectrum of $\beta$-CD-CUR inclusion complex indicated a shift in $\mathrm{H}-3$ from $3.643 \mathrm{ppm}$ to $3.790 \mathrm{ppm}$ (shifted by +0.147 ppm) and H-5 from 3.606 ppm to 3.679 ppm (shifted by $+0.073 \mathrm{ppm})$. The shifts in $\mathrm{H}-3$ and $\mathrm{H}-5$ were bigger than $\mathrm{H}-1$ (+0.002 ppm), H-2 (-0.040 ppm), H-4 (+0.004 ppm), and $\mathrm{H}-6$ (-0.012 ppm). Thus, the shifts in $\mathrm{H}-3$ and $\mathrm{H}-5$ located inside the cavity of $\beta$-CD confirm the formation of an inclusion complex (Jahed et al. 2014). Other than that,

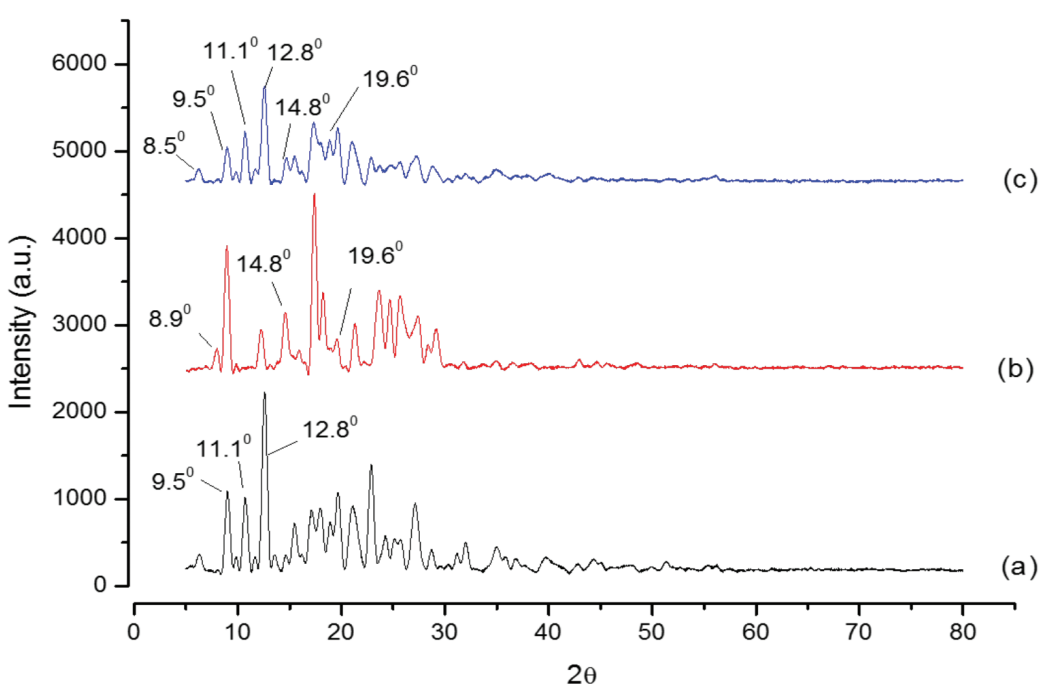

FIGURE 3. X-ray diffractogram of (a) $\beta$-CD, (b) CUR, and (c) $\beta$ CD-CUR inclusion complex 
(a)
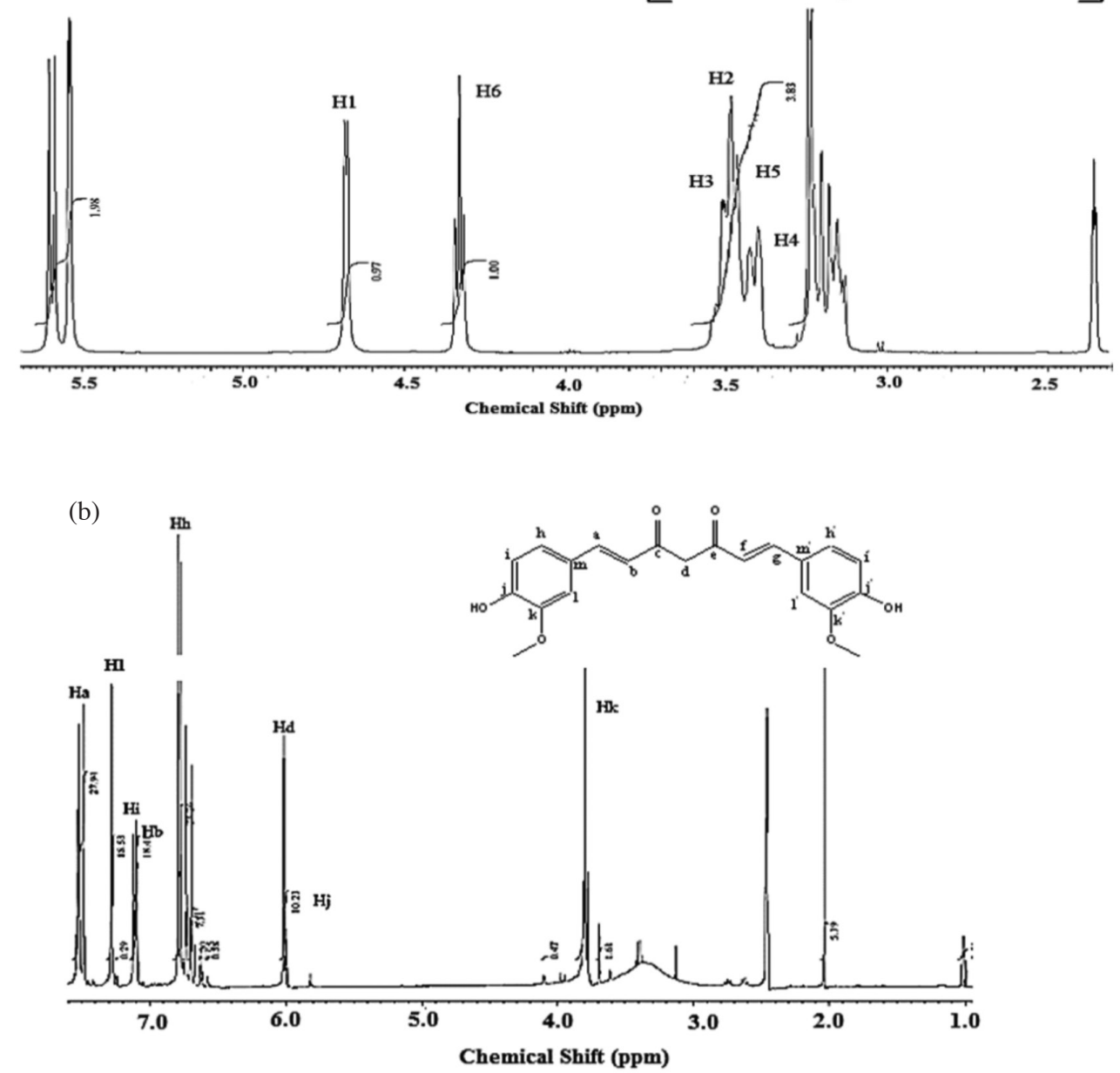

(c)

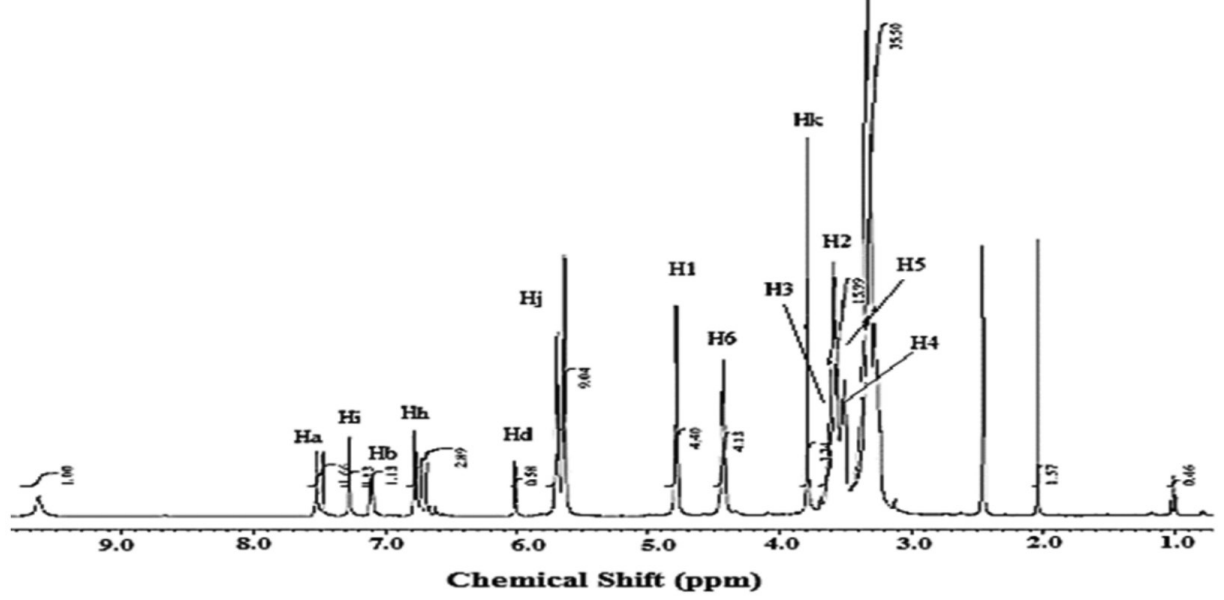

FIGURE 4. NMR spectrum of (a) $\beta$-CD, (b) CUR, and (c) $\beta C D-C U R$ inclusion complex 
TABLE 4. Chemical shifts $(\delta)$ of $\beta$-CD, CUR and $\beta$-CD-CUR inclusion complex

\begin{tabular}{ccccc}
\hline & $\beta-\mathrm{CD}$ & CUR & $\beta$-CD-CUR & \\
\cline { 2 - 5 } & $\Delta \delta(\mathrm{ppm})$ & $\Delta \delta(\mathrm{ppm})$ & $\Delta \delta(\mathrm{ppm})$ & $\Delta \delta(\mathrm{ppm})$ \\
\hline $\mathrm{H} 1$ & 4.786 & & 4.788 & +0.002 \\
$\mathrm{H} 2$ & 3.629 & & 3.589 & -0.040 \\
$\mathrm{H} 3$ & 3.643 & & 3.790 & $\mathbf{+ 0 . 1 4 7}$ \\
H4 & 3.566 & & 3.570 & +0.004 \\
H5 & 3.606 & & 3.679 & $\mathbf{+ 0 . 0 7 3}$ \\
H6 & 4.443 & & 4.431 & -0.012 \\
Ha & & 7.526 & 7.533 & +0.007 \\
Hd & & 6.000 & 6.002 & +0.002 \\
Hg & & 7.526 & 7.533 & +0.007 \\
Hh & & 6.793 & 6.786 & -0.007 \\
Hi & & 7.121 & 7.239 & $\mathbf{+ 0 . 1 1 8}$ \\
Hj & & 5.750 & 5.820 & $\mathbf{+ 0 . 0 7 0}$ \\
Hk & & 3.795 & 3.790 & -0.005 \\
H1 & & 7.282 & 7.273 & -0.009 \\
\hline
\end{tabular}

Values in bold refer to the highest chemical shift of that particular proton

the slight marginal shift of protons $\mathrm{H}-2$ and $\mathrm{H}-4$ suggests CUR as an interaction only with the internal hole of $\beta-C D$ and it is not involved in solubility enhancement of CUR (Jahed et al. 2014). The same phenomenon is observed in $\mathrm{H}-1$ and H-6. Spectrum shifts for CUR to inclusion complex can be observed in Table 3.3. For the spectrum of a symmetrical compound, two carbons will have similar peaks. For example, in CUR, both $\mathrm{Ha}$ and $\mathrm{Hg}$ will have a peak at $7.526 \mathrm{ppm}$. The spectrum belonging to the aromatic ring in CUR shows the most significant shifts at $\mathrm{Hi}(+0.118 \mathrm{ppm})$ and $\mathrm{Hj}(+0.070 \mathrm{ppm})$, suggesting that the aromatic group of CUR reacted with the inner cavity of $\beta$-CD. Moreover, the presence of ${ }^{1} \mathrm{H}$ signal from both CUR and $\beta$-CD in the $\beta$-CD-CUR ${ }^{1} \mathrm{H}$ NMR spectrum indicates the formation of a new inclusion complex.

\section{CORRELATION SPECTROSCOPY (COSY) ANALYSIS}

$2 \mathrm{D}{ }^{1} \mathrm{H}-{ }^{1} \mathrm{H}$ COSY spectroscopic technique was studied which is a powerful technique to investigate the intermolecular interaction and confirm the formation of the inclusion complex (Raoov et al. 2013). Besides that, 2D NMR enables us to determine the interaction between the guest and the host molecules in the complexes and the connectivity between their neighbouring protons in the cavity of the inclusion complex (Gómez-Galván et al. 2016). The ${ }^{1} \mathrm{H}$ NMR results showed the presence of a guest molecule inside the cavity of $\beta-\mathrm{CD}$ and can be confirmed by $2 \mathrm{D}$ COSY (Mohamad et al. 2011). The cross-peak in Figure 5 originates from the interaction of protons of $\beta$-CD and CUR. The cross peak at 3.679-3.790 ppm which belongs to $\beta-\mathrm{CD}$ (H-3 and $\mathrm{H}-5)$ and the aromatic region of CUR at $5.82 \mathrm{ppm}$

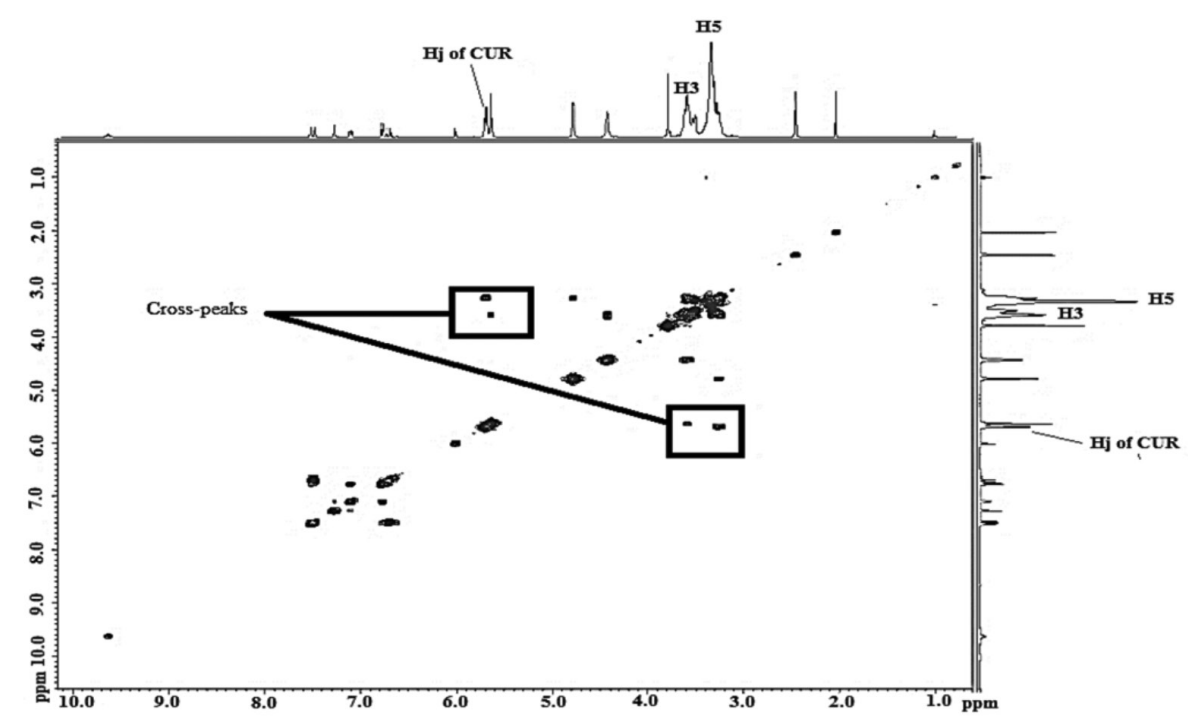

FIGURE 5. The correlation spectra of $\beta$ CD-CUR inclusion complex in DMSO 
demonstrates strong intensity. Therefore, we can conclude that the aromatic ring of CUR has entered the cavity of $\beta-\mathrm{CD}$.

\section{SCANNING ELECTRON MICROSCOPE (SEM) ANALYSIS}

SEM studies were conducted to investigate the morphology of $\beta$-CD, CUR and $\beta$ CD-CUR inclusion complex (Figure 6). SEM pictures showed that $\beta$-CD has a crystalline flake-like structure throughout the sample. CUR on the other hand shows a highly rod-like spherical crystals. However, the $\beta$-CD-CUR inclusion complex does not show neither crystalline flakes nor spherical-crystals. Instead, the $\beta C D-$ CUR inclusion complex exhibits a combination of large and small irregular-shaped clumps. The morphological change from flake-like structure to smaller aggregates is due to CUR encapsulation in the cavities of $\beta$-CD. The morphology obtained was in a good agreement with few studies (Rachmawati et al. 2013; Yallapu et al. 2010).

\section{THERMOGRAVIMETRIC ANALYSIS (TGA) ANALYSIS}

TGA is a frequently used technique for measuring a compound's thermal stability in which TGA will be done on samples to identify the changes in weight percent with respect to temperature change (Sambasevam et al.2013)1H Nuclear Magnetic Resonance (1H NMR. In this study, the thermal stability of $\beta$ CD-CUR was evaluated using TGA and the results were compared with pure $\beta-\mathrm{CD}$ and free Curcumin. Figure 7 shows the weight loss curves for $\beta-\mathrm{CD}$ CUR and its precursors in the temperature range of $0-800^{\circ} \mathrm{C}$. $\beta \mathrm{CD}$ started to decompose at $320^{\circ} \mathrm{C}$. Visible changes occurred at $120^{\circ} \mathrm{C}$ due to the endothermic behaviour which corresponded to the loss of water molecules in $\beta \mathrm{CD}$ cavity. Meanwhile, Curcumin exhibited weight losses at $240^{\circ} \mathrm{C}$ and $450^{\circ} \mathrm{C}$ which were due to the degradation of benzyl part. Then the inclusion complex underwent weight losses in three stages and lost $95 \%$ of its original weight at $730^{\circ} \mathrm{C}$. The first stage is due to the dehydration of water molecules while the second stage is due to decomposition of $\beta-\mathrm{CD}$ and the third stage is probably due to the decomposition of Curcumin. The degradation and weight loss steps of the samples are shown in Table 5.

\section{SPECTROSCOPIC STUDIES}

Effect of $\mathrm{pH}$ The effect of $\mathrm{pH}(\mathrm{pH} \mathrm{4,7}$ and 10) has been studied in order to determine the optimum $\mathrm{pH}$ of inclusion (a)

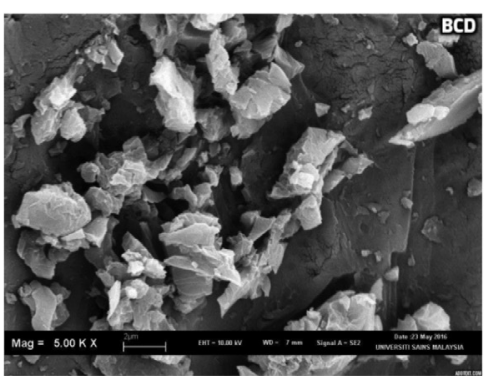

(b)

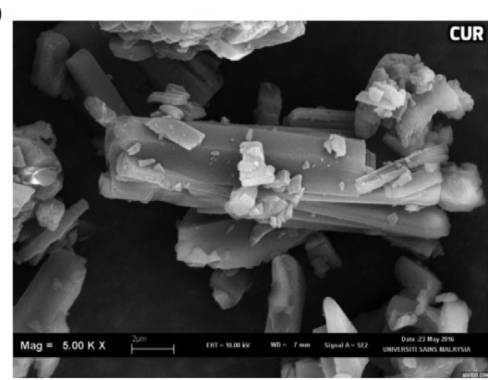

(c)

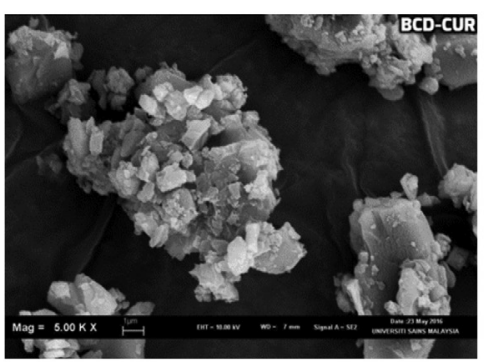

FIGURE 6. The Scanning Electron Microscope photographs of (a) $\beta-C D$, (b) CUR,

(c) $\beta$-CD-CUR inclusion complex observed under $5000 \times$ magnification

TABLE 5. Thermo gravimetric analysis result of samples

\begin{tabular}{cccc}
\hline Sample & Region $\left({ }^{\circ} \mathrm{C}\right)$ & Weight loss $(\%)$ & Assignment \\
\hline$\beta$-CD & 120 & 11.0 & Water loss \\
& $320-480$ & 85.0 & $\beta$-CD \\
Curcumin & 240 & 3.00 & Benzyl \\
& 450 & 50.0 & $\mathrm{C}=\mathrm{O}$ \\
$\beta$-CD-CUR & 110 & 9.00 & Water loss \\
& 320 & 18.0 & $\beta$-CD \\
& 730 & 95.0 & Curcumin \\
\hline
\end{tabular}




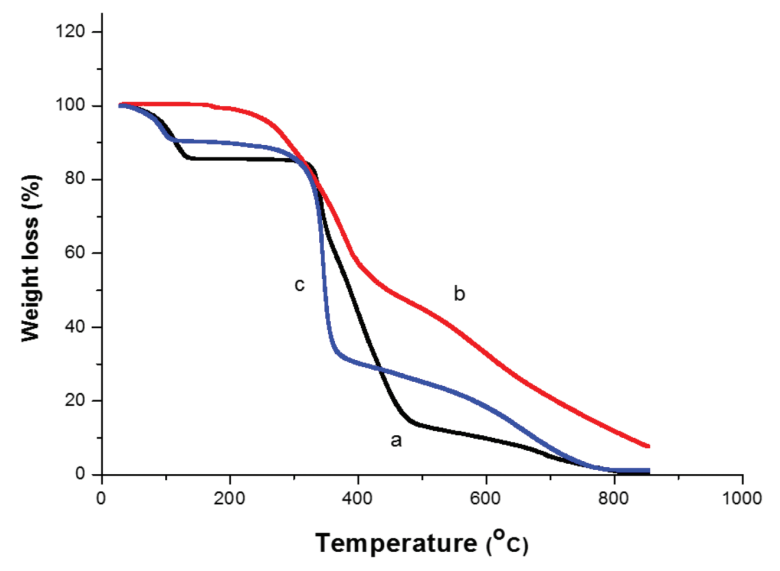

FIGURE 7. TGA curves of (a) $\beta$-CD; (b) Curcumin; (c) $\beta$-CD-CUR

formation between $\beta$-CD and Curcumin. No absorbance was observed for $\mathrm{pH} 10$ (as shown in Figure 8). $\mathrm{pH} 7$ (at $426 \mathrm{~nm}$ ) was chosen to be the optimum $\mathrm{pH}$ rather than $\mathrm{pH} 4$ for this inclusion complex due to the ease of experimental preparation. This is a phenomena where at $\mathrm{pH} 7$, Curcumin is weak and less stable (Jha et al. 2016) and able to form highly stable inclusion complex with $\beta$-CD. Besides that, neutral forms of Curcumin are also predominant at neutral $\mathrm{pH}$ which ease the formation of inclusion complex.

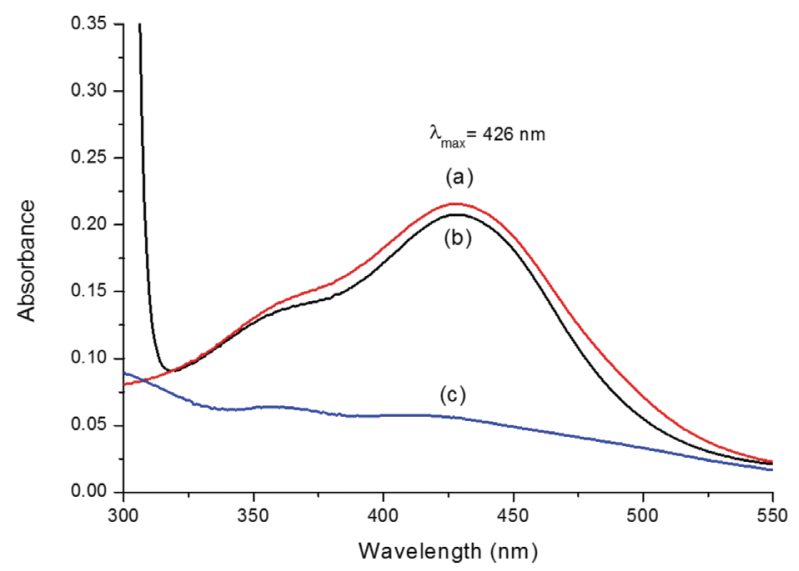

FIGURE 8. The effect of $\mathrm{pH}$ on absorption spectra of (a) $\mathrm{pH} 7$; (b) $\mathrm{pH} 4$ and (c) $\mathrm{pH} 10$

\section{ABSORPTION SPECTRA}

Absorption spectra were used to confirm the formation of inclusion complex. The absorption spectra of $\beta$-CD-CUR complex, CUR and $\beta$-CD were recorded with accordance to procedure in Section Spectroscopic Studies. The obtained result showed that $\beta-\mathrm{CD}$ had no absorption in the range of 300-500 $\mathrm{nm}$. While CUR had a maximum absorption wavelength at $419 \mathrm{~nm}$, the absorbance of $\beta$-CD-CUR was higher than that of CUR at $426 \mathrm{~nm}$ as shown in Figure
9. Based on the result, the increase on the absorbance intensity of the complex was due the formation of the inclusion complex with the $\beta-\mathrm{CD}$. This can be proven by the fact that increase and shift on the intensities were rationalized act as the indicator of inclusion complex formation (Wang et al. 2007). The influence of $\beta-C D$ concentration on CUR was also studied. As can be seen in Figure 3.9, the addition of $\beta$-CD had caused a noticeable increase in the absorption intensity. This is due to the structure of Curcumin that contains two aromatic ring systems possessing o-methoxy phenolic groups which can be included by $\beta$-CD cavity molecule. Upon inclusion in the $\beta$-CD cavity, generally the absorbance of the guest molecule will be enhanced due to the shielding of the excited species from no-radiative processes occurring in the bulk solution and also due to the increase in molar absorption coefficient of the inclusion complex $(\beta-\mathrm{CD}$ CUR) (Mohamad et al. 2011).

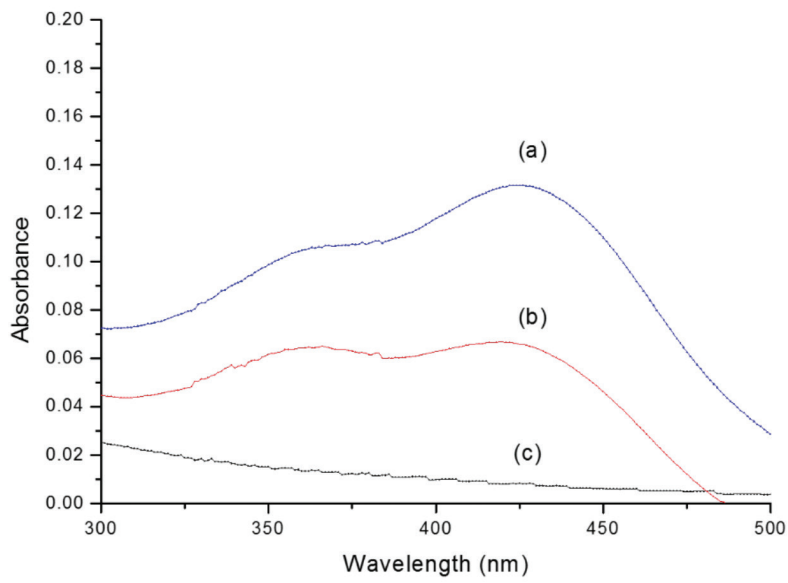

FIGURE 9. The absorption spectra of (a) $\beta$-CD-CUR inclusion complex, (b) CUR, and (c) $\beta-\mathrm{CD}$ at $\mathrm{pH} 7$ with $[\beta-\mathrm{CD}]: 0.0032 \mathrm{M}$ and [CUR]: $0.00005 \mathrm{M}$ at ${ }_{\text {max }}=426 \mathrm{~nm}$

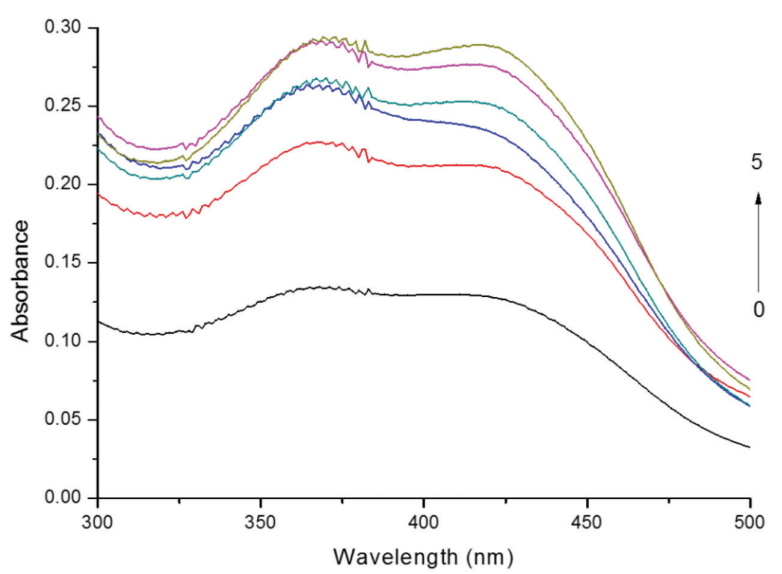

FIGURE 10. Absorption spectra of [CUR] $=0.00005 \mathrm{M}$ with various concentrations of $\beta-\mathrm{CD}$ at $\mathrm{pH} 7$. From lines 0 to $5: 0 \mathrm{M} ; 0.001 \mathrm{M}$; $0.002 \mathrm{M} ; 0.003 \mathrm{M} ; 0.004 \mathrm{M} ; 0.005 \mathrm{M}$ at ${ }_{\max }=426 \mathrm{~nm}$ 


\section{STOICHIOMETRY OF THE COMPLEX AND FORMATION CONSTANT}

The formation constant is the most important parameter in the study of inclusion behaviour of $\beta-\mathrm{CD}$. The formation constant for the inclusion complex has been determined by analysing the changes in the intensities of absorption with different concentrations. The formation constant was denoted and the stoichiometric ratio of the $\beta$-CDCUR was determined using modified Benesi-Hildebrand equation (Wang et al. 2007). The K value was calculated by dividing the slope with the intercept of straight line obtained from the double reciprocal plot. The apparent formation constant was determined to be $1.093 \times 10^{-8}$ $\mathrm{mol}^{-1} \mathrm{dm}^{-3}$. Hence, we propose that the CUR ideally tends to form inclusion complex in 2:1 ratio due to the presence of two aromatic rings and this can be proved (Wang et al. 2007) by the good linear relationship obtained when is plotted against with $\mathrm{R}^{2}=0.9943$ for $\beta$-CD-CUR (Figure 11 ), indicating that the stoichiometric ratio of the complex formed should be $2: 1$.

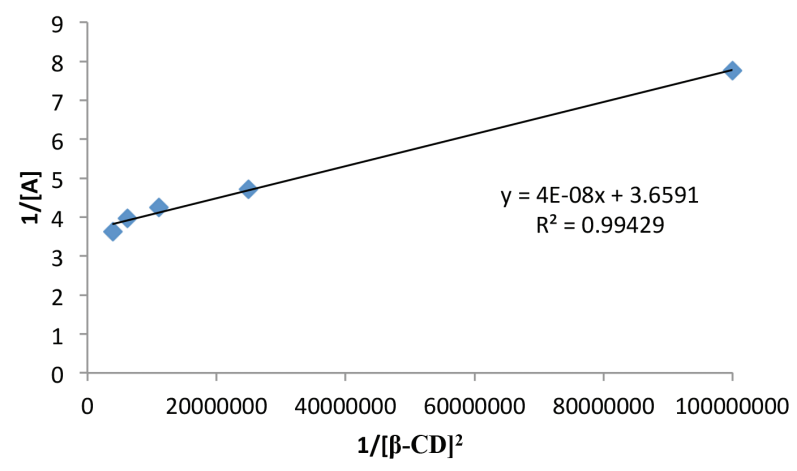

FIGURE11. Reciprocal plot for $1 / \mathrm{A}$ against $1 /[\beta-\mathrm{CD}]^{2}$ of ideal $\beta$-CD-CUR inclusion complex

\section{INCLUSION STRUCTURE}

The possible inclusion mechanism was proposed from the stoichiometric ratio 2:1 as predicted using BenesiHildebrand equation. This is the same finding proposed by Jahed et al. (2014) in which from the result of NMR, it was observed that $\beta$-CD interacts with CUR in $2: 1$ ratio. It also shows that in a stable complex, two aromatic rings of CUR interact with two $\beta$-CDs through the hydrogen bonds as shown in Figure 12.

\section{ANTI-PROLIFERATIVE STUDIES}

Figure 13 shows the comparison of anti-proliferative effects of $\beta$-CD-CUR inclusion complex versus CUR alone at $24 \mathrm{~h}$ and $48 \mathrm{~h}$ of incubation periods, respectively. At 24 $\mathrm{h}$ time point, the percentage of cell death for CUR (curve a) treated cells range from $30.4-64.8 \%$. The data showed that $100 \mu \mathrm{M}$ of CUR alone inhibited the highest cell proliferation of MCF- 7 cells, which is at $64.8 \%$. However, the percentage of cell death decreased when the concentration of CUR

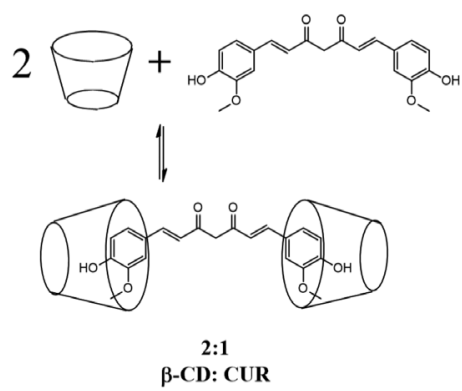

FIGURE 12. Proposed inclusion structure of $\beta$-CD-CUR in ratio $2: 1$

increased, where CUR at the highest concentration (250 $\mu \mathrm{M}$ ) led to only $30.4 \%$ of growth inhibition in MCF-7 cells. Importantly, anti-proliferative effect of CUR was potentiated by the presence of the $\beta-\mathrm{CD}$. The percentage of cell death was increased from $61.75 \%$ to $73.07 \%$ in MCF- 7 cells treated with $\beta$-CD-CUR inclusion complex in which $150 \mu \mathrm{M}$ concentration of the complex caused the greatest cell inhibition. This shows a trend that percentages of cell death decreased with increasing of $\beta$-CD-CUR concentration. At $48 \mathrm{~h}$ of incubation period, CUR alone (curve a) inhibited the growth of MCF-7 cells in a dose-dependent manner, in which the maximum anti-proliferative effect was obtained at concentration of $200 \mu \mathrm{M}$, with $95.1 \%$ of cell death. $\beta$-CDCUR complex at $250 \mu \mathrm{M}$ concentration inhibited $90.65 \%$ growth of MCF-7 cells. Within $48 \mathrm{~h}$ incubation period, the percentage of cell death increased proportionally with the increasing concentration of $\beta$-CD-CUR inclusion complex. CUR alone needs longer incubation period ( $48 \mathrm{~h}$ ) to show its anti-proliferative efficacy in killing MCF-7 cancerous cells, whilst $\beta$-CD co-treatment shortens the time exposure for CUR to induce cytotoxic of MCF-7 cells within $24 \mathrm{~h}$ of incubation period. These data also demonstrate that $\beta$-CDCUR inclusion complex potently inhibited the MCF-7 cells greater than CUR alone, particularly at $24 \mathrm{~h}$ post-treatment at all concentrations tested in this study. The addition of $\beta$-CD has potentiated and enhanced the water solubility of CUR probably accounts for the favourable effect (Jahed et al. 2014), thus speeding up their efficacy to prevent the growth of MCF-7 cells compared to the treatment of CUR alone. This suggests that $\beta$-CD delivery is more efficient for curcumin and is therefore a preferred vehicle or a drug carrier.

Figure 14 shows the anti-proliferative effects for all treatments, including negative control (untreated cells), positive control (tamoxifen-treated cells), CUR alone, $\beta$-CD alone, as well as $\beta$-CD-CUR inclusion complex at both 24 $\mathrm{h}$ and $48 \mathrm{~h}$, respectively. At $24 \mathrm{~h}$ of incubation period, the percentage of cell viability reached $103 . \%$ at $50 \mu \mathrm{M}$ of $\beta$-CD, whilst showing a decrease to $29.63 \%$ in $150 \mu \mathrm{M}$ of $\beta$-CD-treated cells. Nonetheless, the highest concentration of $\beta$-CD alone only caused little cytotoxicity (less than $10 \%$ of cell death) at $48 \mathrm{~h}$ incubation period. $\beta$-CD-CUR inclusion complex potently decreased the proliferation of MCF- 7 cells, where only $27 \%$ and $9 \%$ of viable cells were 

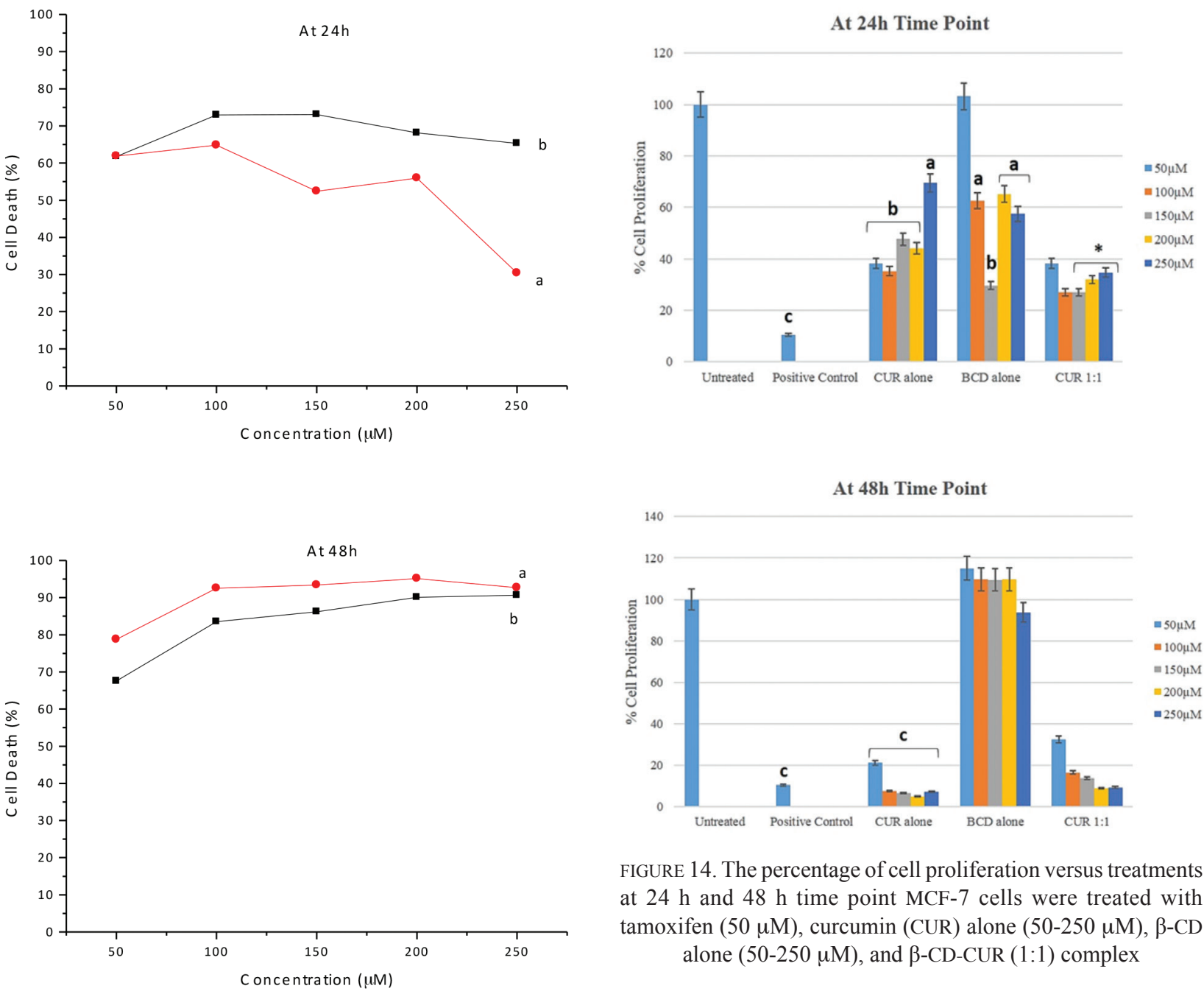

FIGURE 14. The percentage of cell proliferation versus treatments at $24 \mathrm{~h}$ and $48 \mathrm{~h}$ time point MCF-7 cells were treated with tamoxifen $(50 \mu \mathrm{M})$, curcumin (CUR) alone $(50-250 \mu \mathrm{M}), \beta-\mathrm{CD}$ alone $(50-250 \mu \mathrm{M})$, and $\beta$-CD-CUR (1:1) complex

FIGURE 13. The cytotoxic effects of curcumin (CUR) alone (curve a) and $\beta$-CD-CUR inclusion complex (curve b) at 5 different concentrations after $24 \mathrm{~h}$ and $48 \mathrm{~h}$ treatments

observed at $24 \mathrm{~h}$ and $48 \mathrm{~h}$ post-treatment, respectively. Overall, $\beta$-CD-CUR inclusion complex shows a significant anti-proliferative effect with more than $70 \%$ of cell death obtained at all concentrations tested in this study.

Data shown are the mean values \pm S.D. for three independent experiments. Statistical analyses were determined using Independent $t$ test with ${ }^{\mathrm{a}} \mathrm{p}<0.05,{ }^{\mathrm{b}} \mathrm{p}<0.01$, ${ }^{c} p<0.001$, significantly different to control (untreated sample) and ${ }^{*} \mathrm{p}<0.05, \beta$-CD-CUR compared to CUR alone

\section{CONCLUSION}

In this study, we have demonstrated the feasibility of $\beta-\mathrm{CD}$ to encapsulate Curcumin via inclusion complexation by using kneading technique. Our study shows that Curcumin was efficiently encapsulated into the cavity of $\beta-\mathrm{CD}$ and the formation of the inclusion complex was confirmed in the characterization part using FTIR, SEM, TGA, ${ }^{1} \mathrm{H}$ NMR and XRD. The chemical shifts in each characterization showed pattern or characteristics from their parent molecule in the

inclusion complex with slight shifts and differences. Based on the anti-proliferative study, we can conclude that the $\beta$-CD is a potential bioorganic drug delivery carrier since it has shown to be effective in inhibiting the growth of MCF-7 cells by not only increasing the solubility and enhancing Curcumin delivery while promoting and improving the anti-proliferative effect of CUR during the complexation rather than CUR alone at $24 \mathrm{~h}$ incubation period. Our study brings the idea to support the use of $\beta$-CDs as a key tool to improve the pharmaceutical and pharmacological aspects of Curcumin for turning these widely available natural products into effective drugs.

\section{ACKNOWLEDGEMENTS}

This study was funded by the Research University Individual (RUI) grant 1001/CIPPT/812197, USM Short Term Grant 304/CIPPT/6313228 and Fundamental Research Grant Scheme, Ministry of Higher Education (MOHE), Malaysia (FRGS, 203/CIPPT/6711557).

\section{REFERENCES}

Bar-Sela, G., Epelbaum, R. \& Schaffer, M. 2010. Curcumin as an anti-cancer agent: Review of the gap between basic 
and clinical applications. Current Medicinal Chemistry 17: 190-197.

Danhier, F., Olivier, F. \& Véronique, P. 2010. To exploit the tumor microenvironment: Passive and active tumor targeting of nanocarriers for anti-cancer drug gelivery. Journal of Controlled Release 148(2): 135-146.

Fermeglia, M., Ferrone, M., Lodi, A. \& Pricl, S. 2003. Hostguest inclusion complexes between anticancer drugs and $\beta$-Cyclodextrin: Computational studies. Carbohydrate Polymers 53(1): 15-44.

Gafner, S., Sang, K.L., Muriel, C., Sophie, B., Laurent, V., Serge, L., Rajendra, G.M., Charles, W.B. \& John, M.P. 2004. Biologic evaluation of curcumin and structural derivatives in cancer chemoprevention model systems. Phytochemistry 65: 2849-2859.

Gómez-Galván, F., Pérez-Álvarez, L., Janire, M., ÁlvarezBautista, A., Joana, P., Catarina, M.D., Ruiz-Rubio, L., Vila-Vilela, J.L. \& Luis, M.L. 2016. Preparation and characterization of soluble branched ionic $\beta$-Cyclodextrins and their inclusion complexes with triclosan. Carbohydrate Polymers 142: 149-157.

Holder, G.M., Plummer, J.L. \& Ryan, A.J. 1978. The metabolism and excretion of curcumin (1,7-Bis-(4-Hydroxy-3Methoxyphenyl)-1,6-Heptadiene-3,5-Dione) in the rat. Xenobiotica; the Fate of Foreign Compounds in Biological Systems 8(12): 761-768.

Jabbarzadeh, K.P., Asmah, R., Patimah, I. \& Kingm, H.L. 2014. Targets and mechanisms of berberine, a natural drug with potential to treat cancer with special focus on breast cancer. European Journal of Pharmacology 740: 584-595.

Jahed, V., Ali, Z., Khalegh, B.A. \& Mohammad, S.H. 2014. NMR (1H, ROESY) spectroscopic and molecular modelling investigations of supramolecular complex of $\beta$-Cyclodextrin and curcumin. Food Chemistry 165: 241-246.

Jha, N.N., Dhiman, G., Subhadeep, D.,Arunagiri, A., Reeba, S.J., Pradeep, K.S., Narasimham, A., Irishi, N.N.N. \& Samir, K.M. 2016. Effect of curcumin analogs On $\alpha$-Synuclein aggregation and cytotoxicity. Scientific Reports 6: 28511.

Khan, M.A., Zafaryab, M., Mehdi, S.H., Ahmad, I. \& Rizvi, M.M. 2016. Characterization and anti-proliferative activity of curcumin loaded chitosan nanoparticles in cervical cancer. International Journal of Biological Macromolecules 93(Part A): 242-253

Kuntz, I.D., Gasparro, F.P., Johnston, M.D. \& Taylor, R.P. 1968. Molecular interactions and the benesi-hildebrand equation. Journal of the American Chemical Society 90(18): 47784781.

Li, L., Fadi, S.B. \& Razelle, K. 2005. Liposome-encapsulated curcumin. Cancer 104(6): 1322-1331.

Liu, Z., Yusheng, S., Luqing, R., Yi, H., Yuepiao, C., Qiaoyou, W., Xueqian, S., Xiaokun, L., Guang, L. \& Yi, W. 2013. Evaluation of a curcumin analog as an anti-cancer agent inducing ER stress-mediated apoptosis in non-small cell lung cancer cells. BMC Cancer 13(1): 494.

Mangolim, C.S., Cristiane, M., Ana, C.N., Francielle, S., Mauro, L.B., Antônio, M.N. \& Graciette, M. 2014. Curcumin$\beta$-Cyclodextrin inclusion complex: Stability, solubility, characterisation by FT-IR, FT-Raman, X-ray diffraction and photoacoustic spectroscopy, and food application. Food Chemistry 153: 361-370.

Memisoglu-Bilensoy, E., Vural, I., Bochot, A., Renoir, J.M., Duchene, D. \& Hincal, A.A. 2005. Tamoxifen citrate loaded amphiphilic $\beta$-Cyclodextrin nanoparticles: In vitro characterization and cytotoxicity. Journal of Controlled Release 104(3): 489-496.

Mohamad, S., Hemavathy, S., Muggundha, R., Tilagam, M., Kumuthini, C. \& Puvaneswary, S. 2011. Conventional study on novel dicationic ionic liquid inclusion with $\beta$-Cyclodextrin. International Journal of Molecular Sciences 12: 6329-6345.

Rachmawati, H., Citra, A.E. \& Rachmat, M. 2013. Molecular inclusion complex of curcumin- $\beta$-Cyclodextrin nanoparticle to enhance curcumin skin permeability from hydrophilic matrix gel. AAPS PharmSciTech 14(4): 1303-1312.

Raoov, M., Mohamad, S. \& Abas, M.R. 2013. Removal of 2,4-Dichlorophenol using cyclodextrin-ionic liquid polymer as a macroporous material: Characterization, adsorption isotherm, kinetic study, thermodynamics. Journal of Hazardous Materials 263: 501-516.

Salem, M., Ying, X., Alison, A. \& Elizabeth, R.G. 2015. RSC advances magnetite particles for targeted drug delivery. RSC Advances 5: 37521-37532.

Sambasevam, K.P., Mohamad, S., Norazilawati, M.S. \& Ismail, N.A. 2013. Synthesis and characterization of the inclusion complex of $\beta$-Cyclodextrin and azomethine. International Journal of Molecular Sciences 14: 3671-3682.

Sou, K., Shunsuke, I., Shinji, T. \& Eishun, T. 2008. Loading of curcumin into macrophages using lipid-based nanoparticles. International Journal of Pharmaceutics 352(1-2): 287-293.

Subramaniam, P., Mohamad, S. \& Yatimah, A. 2010. Synthesis and characterization of the inclusion complex of dicationic ionic liquid and $\beta$-Cyclodextrin. International Journal of Molecular Sciences 11(10): 3675-3685

Ucar, E., Serap, T., Cigdem, I., Ayfer, Y.K., Medine, E.I., Kadir, A., Yasemin, P., Elvan, B.S.B.\& Perihan, U. 2017. Synthesis, characterization and radiolabeling of folic acid modified nanostructured lipid carriers as a contrast agent and drug delivery system. Applied Radiation and Isotopes 119: 72-79.

Wan Omar, W.A.,Azhar, N.A., Nurdianah, H.F. \& Nik Mohamed Kamal, N.N.S. 2016. Bee pollen extract of Malaysian stingless bee enhances the effect of cisplatin on breast cancer cell lines. Asian Pacific Journal of Tropical Biomedicine 6(3): 265-269.

Wang, H.Y., Juan, H. \& Xia, G.F. 2007. Spectroscopic study of orange G- $\beta$-Cyclodextrin complex and its analytical application. Spectrochimica Acta - Part A: Molecular and Biomolecular Spectroscopy 66(3): 578-585.

Wilken, R., Mysore, S.V., Marilene, B.W. \& Eri, S.S. 2011. Curcumin: A review of anti-cancer properties and therapeutic activity in head and neck squamous cell carcinoma. Molecular Cancer 10(1): 12.

Williams III, R.O., Vorapann, M. \& Mongkol, S. 1998. Characterization of an inclusion complex of cholesterol and hydroxypropyl- $\beta$-Cyclodextrin. European Journal of Pharmaceutics and Biopharmaceutics 46(3): 355-360.

Yallapu, M.M., Meena, J. \& Subhash, C.C. 2010. $\beta$-Cyclodextrincurcumin self-assembly enhances curcumin delivery in prostate cancer cells. Colloids and Surfaces B: Biointerfaces 79(1): 113-125

Yu, H. \& Qingrong, H. 2010. Enhanced in vitro anti-cancer activity of curcumin encapsulated in hydrophobically modified starch. Food Chemistry 119(2): 669-674.

Zhang, J.Q., Di, W., Kun, M.J., Da, Z., Xi, Z., Chun, P.W., Hong, Y.Z., Xiao, G.X., Yi, J. \& Jun, L. 2015. Preparation, 
spectroscopy and molecular modelling studies of the inclusion complex of cordycepin with cyclodextrins. Carbohydrate Research 406: 55-64.

Muhammad Hasnor Ja'far, Nik Nur Syazni Nik Mohamed Kamal, Boon Yih Hui, Muhammad Fahmi Kamaruzzaman, Nur Nadhirah Mohamad Zain \& Noorfatimah Yahaya Integrative Medicine Cluster

Advanced Medical \& Dental Institute

Universiti Sains Malaysia

13200 Pulau Pinang

Malaysia

Muggundha Raoov*

Department of Chemistry

Faculty of Science

University of Malaya

50603 Kuala Lumpur, Federal Territory

Malaysia
Muggundha Raoov*

Universiti Malaya Centre for Ionic Liquids (UMCiL)

Department of Chemistry

Faculty of Science

University of Malaya

50603 Kuala Lumpur, Federal Territory

Malaysia

*Corresponding author; email: muggundha@um.edu.my

Received: 2 September 2017

Accepted: 5 December 2017 